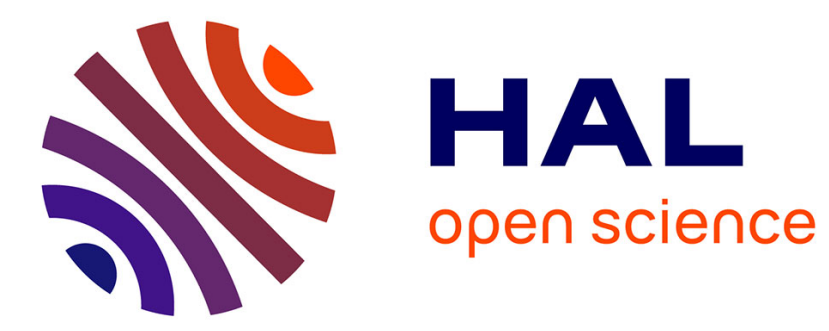

\title{
Feasibility of isolation perimeters for genetically modified maize
}

Yann Devos, Olivier Thas, Mathias Cougnon, Eva M. de Clercq, Karl Cordemans, Dirk Reheul

\section{- To cite this version:}

Yann Devos, Olivier Thas, Mathias Cougnon, Eva M. de Clercq, Karl Cordemans, et al.. Feasibility of isolation perimeters for genetically modified maize. Agronomy for Sustainable Development, 2008, 28 (2), pp.195-206. hal-00886409

\section{HAL Id: hal-00886409 https://hal.science/hal-00886409}

Submitted on 1 Jan 2008

HAL is a multi-disciplinary open access archive for the deposit and dissemination of scientific research documents, whether they are published or not. The documents may come from teaching and research institutions in France or abroad, or from public or private research centers.
L'archive ouverte pluridisciplinaire HAL, est destinée au dépôt et à la diffusion de documents scientifiques de niveau recherche, publiés ou non, émanant des établissements d'enseignement et de recherche français ou étrangers, des laboratoires publics ou privés. 


\title{
Feasibility of isolation perimeters for genetically modified maize
}

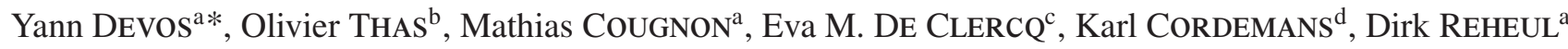 \\ ${ }^{1}$ Department of Plant Production, Faculty of Bioscience Engineering, University of Ghent, Coupure Links 653, 9000 Ghent, Belgium \\ ${ }^{2}$ Department of Applied Mathematics, Biometrics and Process Control, Faculty of Bioscience Engineering, University of Ghent, Coupure Links 653, \\ 9000 Ghent, Belgium \\ ${ }^{3}$ Department of Forest and Water Management, Faculty of Bioscience Engineering, University of Ghent, Coupure Links 653, 9000 Ghent, Belgium \\ ${ }^{4}$ Department of Rural Development, Flemish Land Agency, Gulden Vlieslaan 72, 1060 Brussels, Belgium
}

(Accepted 9 August 2007)

\begin{abstract}
Using geographic information system datasets and Monte Carlo simulations, this study investigates to what extent the intra-regional variability in maize share and field distribution affects the feasibility of implementing isolation perimeters between genetically modified (GM) and non-GM maize fields. More specifically, five scenarios differing in shares and spatial distributions of GM maize were tested for various isolation perimeters in six agricultural areas in Flanders (Belgium). Proportions of non-GM maize fields and farmers having at least one nonGM maize field occurring within isolation perimeters were calculated to assess how spatial co-existence measures would affect the freedom of choice of neighbouring farmers to grow non-GM maize on their fields. Irrespective of the scenario tested, our results demonstrated that the proportions of non-GM maize fields and their corresponding farmers falling within the isolation perimeters are approximately two to eight times higher in areas with the highest maize share than in areas with the lowest maize share. The higher the share of GM maize and the wider the imposed isolation perimeter, the lower the intra-regional differences became. Hence, those findings confirm that farmers will not be equally affected by isolation perimeters, indicating the importance of considering intra-regional differences in the choice of appropriate spatial co-existence measures. Since uniform and wide isolation perimeters tend to be difficult to implement in practice and hardly reflect the diversity of the agricultural landscape, relying on flexible or combining various co-existence measures is worthwhile considering. As an alternative to single co-existence measures for limiting the GM input from cross-fertilisations between neighbouring maize fields, the appropriateness of other on-farm co-existence measures is discussed for Flemish agricultural conditions. Proposing the most appropriate co-existence measures on a case-by-case basis may be one step forward in reaching proportionate, fair and consistent co-existence at the regional and landscape level.
\end{abstract}

adventitious mixing / co-existence / cross-fertilisation / genetically modified crops / geographic information system / isolation perimeters / pollen flow / maize / regional variation / simulations

\section{INTRODUCTION}

The Regulation (EC) 1829/2003 on genetically modified (GM) food and feed that entered into force in April 2004 provides a legal basis for the national and/or regional implementation of co-existence frames in the European Union (EU) (Devos et al., 2006). In accordance with Article 43 of this Regulation, Member States were empowered to take appropriate measures to avoid the unintended presence of genetically modified organisms (GMOs) in other products (EC, 2003b). This co-existence policy aims at making all cropping systems possible and at maintaining agricultural diversity in the EU. Hence, no cropping system should be excluded or favoured over others, and farmers should be able to cultivate the crops they choose be it GM, conventional or organic crops (EC, 2003a; Schiemann, 2003).

Totally avoiding the unintended presence of GMOs in nonGM products will be difficult in the agricultural context (Van De Wiel and Lotz, 2006). Various sources (GM inputs) can contribute to the adventitious mixing between GM and nonGM crops such as the use of impure seed (Friesen et al., 2003),

*Corresponding author: Yann.Devos@UGent.be the natural pollen flow between neighbouring fields (Devos et al., 2005; Sanvido et al., in press), the occurrence of volunteer plants originating from seeds and/or vegetative plant parts from previous GM crops (Devos et al., 2004; Lutman et al., 2005; Messéan et al., 2007), human activities during sowing, harvesting, handling, transporting, storing, importing and processing (Demeke et al., 2006), and - to a lesser extent - the presence of certain sexually compatible wild/weedy relatives and feral plants (Yoshimura et al., 2006; Devaux et al., 2007).

In response to the difficulty of keeping transgenes on a leash (Marvier and Van Acker, 2005), a tolerance threshold of $0.9 \%$ was established for the unintentional or technically unavoidable presence of authorised GM material in non-GM food and feed (EC, 2003b). When the tolerance threshold is exceeded, the co-mingled product has to be labelled as containing a GMO, which may affect its market acceptability. At a meeting of the EU agriculture ministers held on 12 June 2007, it was decided that the $0.9 \%$ threshold would also apply for organic products, meaning that an organic product with an adventitious GMO content below $0.9 \%$ can still be labelled as organic. For seeds no threshold has been defined yet (Devos et al., 2006). 


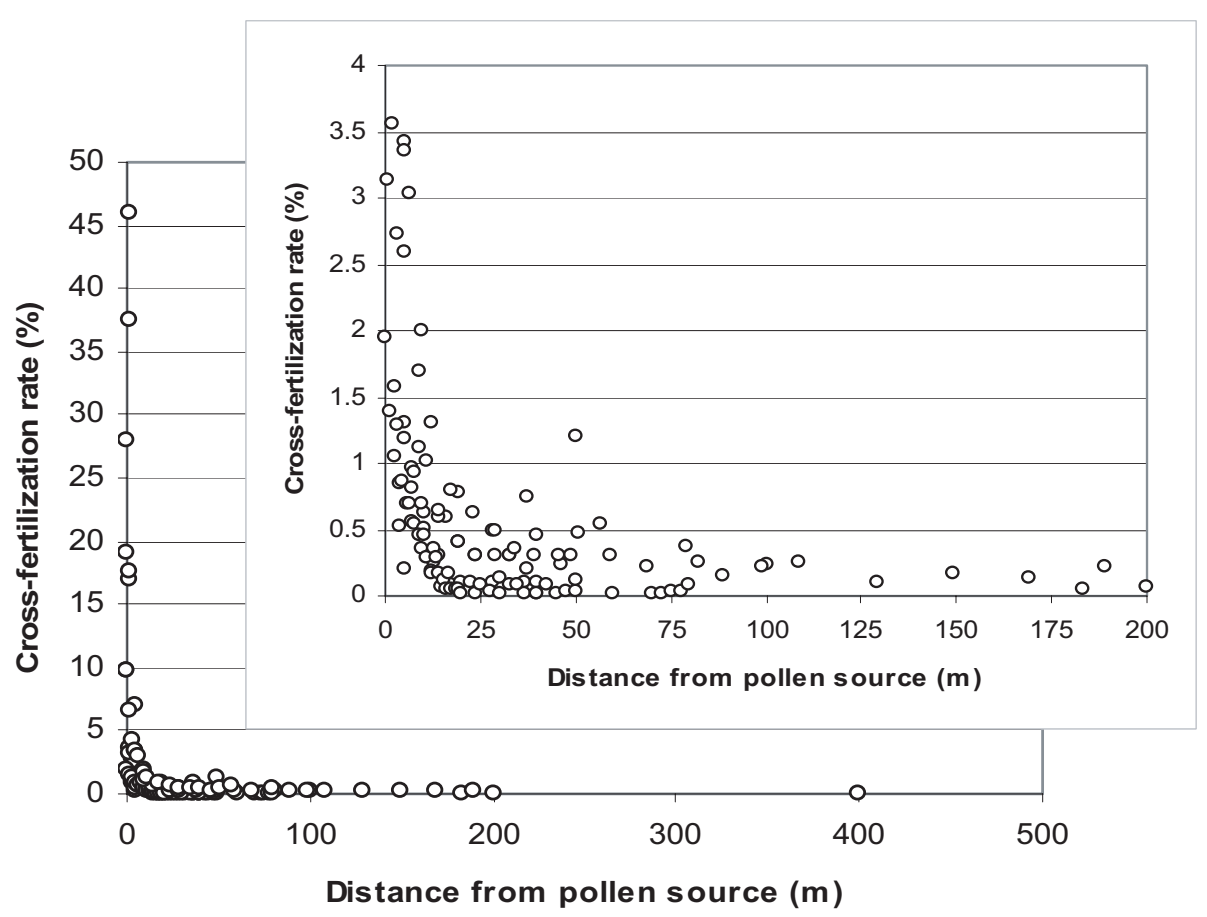

Figure 1. Cross-fertilisation levels (expressed in percentages of maize kernels) in relation to the distance from the pollen source. The upper graph represents a magnification of the original graph. The figure has been reprinted with permission from Sanvido et al. (in press).

In addition to tolerance thresholds, various on-farm measures can be implemented to keep the adventitious GMO content in the harvests of neighbouring non-GM crop fields below the tolerance threshold (EC, 2003a). Since cross-fertilisation levels rapidly decrease with increasing distance from the pollen source, spatially isolating GM crop fields from non-GM ones is a robust strategy to reduce the extent of out-crossing. Compared with other wind-pollinated species, pollen grains of maize are relatively large and heavy. Due to these characteristics, maize pollen settles to the ground rapidly (Aylor et al., 2003) and has a short flight range (Jarosz et al., 2005). While most cross-fertilisations occur within $50 \mathrm{~m}$ of the source (Fig. 1), vertical wind movements or gusts during pollen shedding can lead to very low levels of cross-fertilisation over longer distances (Bannert and Stamp, 2007).

With the registration of various transgenic maize varieties in national catalogues and the common EU catalogue of varieties of agricultural plant species, the commercial cultivation of GM maize is gradually increasing in the EU (Tab. I). Preliminary data for 2007 suggest that the barrier of 100000 ha of GM maize has been exceeded for the first time, with the highest share being grown in Spain (70\%), followed by France (20\%), the Czech Republic (5\%), Portugal (3\%) and Germany (3\%). Accordingly, co-existence between maize cropping systems is becoming a burning issue in some European regions, illustrating the urgent need for legal and practical frames dealing with co-existence. To ensure the spatial isolation of GM maize fields and thus to reduce the GM input from crossfertilisations, national and/or regional authorities are currently implementing or discussing isolation perimeters ranging be- tween 15 and $800 \mathrm{~m}$, frequently favouring a mandatory isolation perimeter of $200 \mathrm{~m}$ (EC, 2006).

One of the drawbacks of exclusively relying on mandatory and rigid isolation perimeters to limit the adventitious GM input from cross-fertilisations at the landscape level is that such an approach does not reflect inter-regional differences in maize share and field distribution. According to the calculations of Dolezel et al. (2005), the proportion of non-GM maize area falling within the isolation perimeter of $200 \mathrm{~m}$, when $10 \%$ of the maize fields are randomly planted with GM maize, ranged between 17 and 59\% among the three studied Austrian regions. In the eastern canton of Zurich (Switzerland), Sanvido et al. (in press) showed that the percentages of maize area neighbouring another maize area within a range of $200 \mathrm{~m}$ varied between 76 and $100 \%$ from one type of landscape to another. Although inter-regional variability has also been indicated as a key parameter for the choice of spatial co-existence measures in the guidelines on co-existence of the European Commission (EC, 2003a), this variability seems to be poorly accommodated in national and/or regional legal co-existence frames (EC, 2006).

The objective of this study is to investigate to what extent the intra-regional variability in maize share and field distribution affects the feasibility of implementing isolation perimeters around GM maize fields in the region of Flanders (Belgium). For this purpose, an approach that combines Geographic Information System (GIS) datasets with Monte Carlo simulations was used and applied to six typical maize cultivation areas in Flanders. By comparing these maize cultivation areas, it was assessed how spatial co-existence measures affect 
Table I. List of registered transgenic maize varieties derived from the event MON810 in the common EU catalogue of varieties of agricultural plant species (51 up to April 2007).

\begin{tabular}{lll}
\hline Year of registration & Country & Maize variety \\
\hline 2004 & France & Bolsa, DK513, Elgina, Lévina, Novélis, Olimpica \\
& Spain & Aliacan BT, Aristis BT, Campero BT, Cuartal BT, DKC6550, DKC6575, Gambier BT, Jaral BT, \\
& & PR32P76, PR33P67, Protect \\
2005 & Bacila, DKC4442YG, DKC5784YG, DKC6041YG, Foggia, Helen BT, PR32R43, PR32W04, \\
& PR34N44, PR36R11, Riglos BT, SF1035T, SF1036T, SF1112T \\
2006 & DKC3421YG, PR38F71, PR39F56, PR39V17, Kuratus \\
2007 & Germany & Abrego BT, Asturial BT, Azema YG, Beles Sur, Benji YG, DKC5018YG, DKC6531YG, Evolia YG, \\
& Spain &
\end{tabular}

differently the freedom of choice of neighbouring farmers to grow non-GM maize on their fields.

\section{MATERIALS AND METHODS}

\subsection{Spatial analyses}

Based on the 2004 data of the Belgian Institute for Statistics, six clusters of communes with a high, medium and low percentage of agricultural area cropped with maize were selected in Flanders (Belgium) (Fig. 2): most of the maize in Belgium is grown in Flanders. The selected clusters were scattered all over Flanders and are representative of the Flemish maize cultivation area. The Flemish Land Agency (VLM) provided a digital map of agricultural fields for each cluster, containing information about the cultivated crop, the size of the field, its identification number and its relation number that corresponds to the farmer who uses the field. To perform spatial analyses, the GIS software ArcView 3.1 was used. In each cluster, spatial analyses consisted of randomly delimiting a square of $25 \mathrm{~km}^{2}$ (Fig. 3). In each square, the size of maize fields and the shortest distance between maize fields from edge to edge - with a spatial accuracy of approximately $0.25 \mathrm{~m}$ - were calculated. Distances between maize fields were arranged in distance matrices.

\subsection{Scenarios}

As GM maize is not grown commercially in Flanders yet, five different scenarios that vary in GM maize shares and spatial distributions were simulated in the selected squares:

- S1: $10 \%$ of the farmers with the largest maize areas grow GM maize on their largest maize field

- S2: $10 \%$ of the farmers with the largest maize areas grow GM maize on all their maize fields

- S3: 10, 30, 50 and $70 \%$ of the maize fields are planted randomly with GM maize

- S4: 10 and $30 \%$ of the maize fields are clustered and planted with GM maize

- S5: 10 and 30\% of the farmers, who are selected randomly, grow GM maize on all their maize fields.
Scenarios S1 and S2 are expected to correspond to potential developments in a take-off situation of GM maize plantings. The first GM maize growers will probably be the farmers with the largest maize areas, since they will be able to allocate their co-existence costs over a large maize area. S3 was used to assess the effect of clustering GM maize fields. Two different clustering approaches were tested. Maize fields to be planted with GM maize were grouped into one large cluster per square in S4. S5 was used as a model for on-farm clustering: selected farmers function as islands of GM maize fields.

For each scenario and square, the feasibility of implementing various isolation perimeters was assessed. Isolation perimeters of 10, 25, 50, 75, 100, 150, 200 and $300 \mathrm{~m}$ were chosen based on the scientific literature (Devos et al., 2005; Messéan et al., 2006; Van De Wiel and Lotz, 2006; Sanvido et al., in press) and on legal proposals of some neighbouring Member States (EC, 2006). Isolation perimeters were implemented concentrically around GM maize fields and refer to the area inside the boundary, including the boundary line (see Fig. 1 in Devos et al., 2007).

\subsection{Calculations and statistical analyses}

Based on the distance matrices and attributes of each maize field, the proportions of non-GM maize fields and farmers having at least one non-GM maize field occurring within the isolation perimeters over the entire square were calculated. S1 and S2 are deterministic: farmers and their corresponding maize fields to be planted with GM maize were identified clearly by the scenarios. In S3, S4 and S5, a Monte Carlo analysis was performed. During 10000 independent simulation runs maize fields to be planted with GM maize or farmers that cultivate GM maize on their maize fields were selected randomly, identifying 10000 different combinations of GM maize field allocations. For each simulation run, the proportions of non-GM maize fields and farmers having at least one non-GM maize field occurring within perimeters were calculated. In S4, each simulation run consisted of randomly selecting a first maize field to be planted with GM maize in the square and, subsequently, of selecting the closest neighbouring maize fields, whilst maize farmers were selected randomly in S5. Calculations of the proportions of involved non-GM maize fields and their corresponding farmers were done as given in S3. 


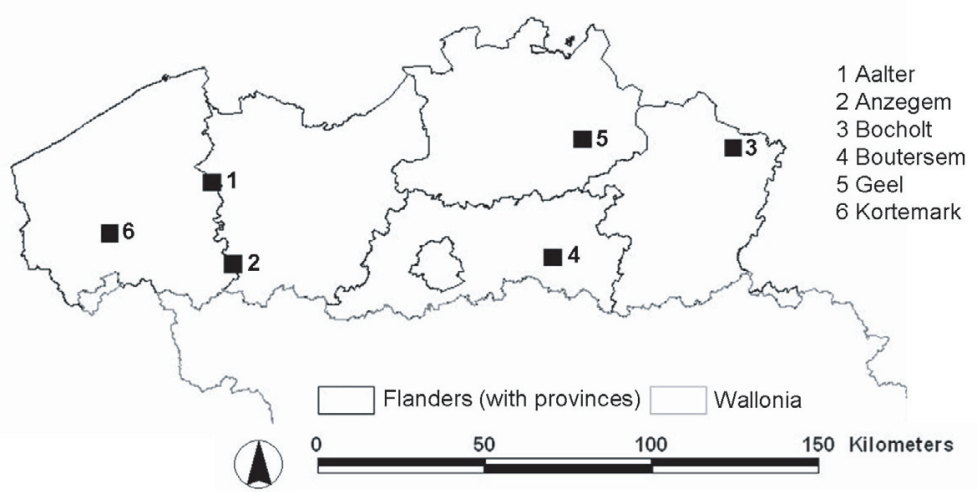

Figure 2. Map of Flanders (Belgium) with six selected squares of $25 \mathrm{~km}^{2}$.

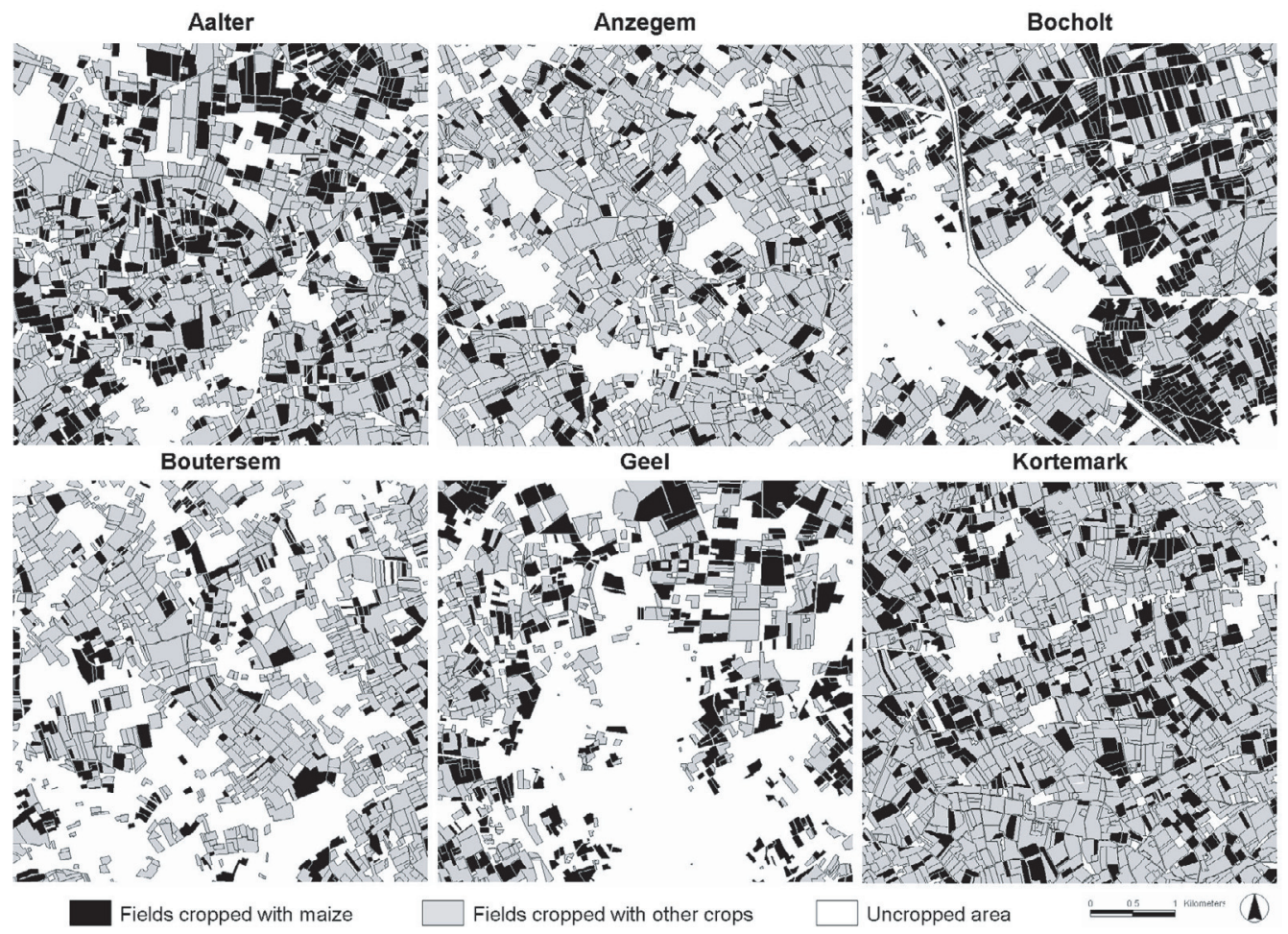

Figure 3. Maps of six selected squares of $25 \mathrm{~km}^{2}$ in Flanders with maize shares of 2004. Pictures adapted from the VLM.

Fields (and their corresponding farmers) occurring within the perimeters of several GM maize fields were counted only once. All calculations were performed in the statistical R 2.3.1 software (see Devos et al., 2007 for further details).

Proportions of non-GM maize fields and farmers having at least one non-GM maize field occurring within an isolation perimeter $(\mathrm{Y})$ were regressed on the isolation perimeter widths (X) using the cubic regression model $\left(\mathrm{Y}=\mathrm{b}_{0}+\mathrm{b}_{1} \mathrm{X}+\mathrm{b}_{2} \mathrm{X}^{2}\right.$ $+b_{3} X^{3}$ ). Data were fitted to the model via a non-linear regression procedure, provided with SPSS14. Regression formulas enable the interpolation of the proportions of non-GM maize fields and their corresponding farmers within the range of isolation perimeters tested.

\section{RESULTS AND DISCUSSION}

\subsection{Characteristics of the selected squares}

The comparison of the area cropped with maize in the selected squares showed that the share of maize varied from $11 \%$ (Anzegem and Boutersem) to 29\% (Bocholt). Expressed on the cropped area within these squares, the maize shares varied from 15\% (Anzegem) to 48\% (Geel) (Tab. II).

The average size of fields cropped with maize ranged between 1.0 ha (Boutersem) and 1.5 ha (Aalter and Geel). The distribution of field sizes was unequal, showing a leptokurtic pattern (Fig. 4). On average, most fields (79\%) were smaller than 2 ha, whilst larger fields (> 4 ha) were rare (5\%). In all 
Table II. Characteristics of the selected squares of $25 \mathrm{~km}^{2}$ in 2004. Between brackets: means \pm standard deviations of 2004,2005 and 2006.

\begin{tabular}{|c|c|c|c|c|c|c|c|c|c|}
\hline Square & $\begin{array}{l}\text { Cropped } \\
\text { area (ha) }\end{array}$ & $\begin{array}{l}\text { Share of } \\
\text { cropped } \\
\text { area in the } \\
\text { square }(\%)\end{array}$ & $\begin{array}{l}\text { Area } \\
\text { cropped } \\
\text { with maize } \\
\text { (ha) }\end{array}$ & $\begin{array}{l}\text { Share of } \\
\text { maize in } \\
\text { cropped } \\
\text { area }(\%)\end{array}$ & $\begin{array}{l}\text { Share of } \\
\text { maize in } \\
\text { square }(\%)\end{array}$ & $\begin{array}{l}\text { Number of } \\
\text { maize } \\
\text { fields }\end{array}$ & $\begin{array}{l}\text { Average size } \\
\text { of maize } \\
\text { fields (ha) }\end{array}$ & $\begin{array}{l}\text { Number of } \\
\text { farmers }\end{array}$ & $\begin{array}{l}\text { Number of } \\
\text { maize fields } \\
\text { per farmer }\end{array}$ \\
\hline Anzegem & $\begin{array}{l}1771 \\
(1729 \pm 54)\end{array}$ & $\begin{array}{l}71 \\
(69 \pm 2)\end{array}$ & $\begin{array}{l}264 \\
(280 \pm 16)\end{array}$ & $\begin{array}{l}15 \\
(16 \pm 1)\end{array}$ & $\begin{array}{l}11 \\
(11 \pm 1)\end{array}$ & $\begin{array}{l}231 \\
(247 \pm 18)\end{array}$ & $\begin{array}{l}1.2 \\
(1.1 \pm 0.0)\end{array}$ & $\begin{array}{l}97 \\
(103 \pm 7)\end{array}$ & $\begin{array}{l}2.4 \\
(2.4 \pm 0.0)\end{array}$ \\
\hline Boutersem & $\begin{array}{l}1272 \\
(1212 \pm 52)\end{array}$ & $\begin{array}{l}51 \\
(49 \pm 2)\end{array}$ & $\begin{array}{l}266 \\
(223 \pm 38)\end{array}$ & $\begin{array}{l}21 \\
(18 \pm 2)\end{array}$ & $\begin{array}{l}11 \\
(9 \pm 2)\end{array}$ & $\begin{array}{l}257 \\
(238 \pm 18)\end{array}$ & $\begin{array}{l}1.0 \\
(0.9 \pm 0.1)\end{array}$ & $\begin{array}{l}73 \\
(72 \pm 2)\end{array}$ & $\begin{array}{l}3.5 \\
(3.3 \pm 0.2)\end{array}$ \\
\hline Geel & $\begin{array}{l}1089 \\
(1123 \pm 31)\end{array}$ & $\begin{array}{l}44 \\
(45 \pm 1)\end{array}$ & $\begin{array}{l}526 \\
(512 \pm 30)\end{array}$ & $\begin{array}{l}48 \\
(46 \pm 4)\end{array}$ & $\begin{array}{l}21 \\
(21 \pm 1)\end{array}$ & $\begin{array}{l}345 \\
(348 \pm 9)\end{array}$ & $\begin{array}{l}1.5 \\
(1.5 \pm 0.1)\end{array}$ & $\begin{array}{l}98 \\
(101 \pm 5)\end{array}$ & $\begin{array}{l}3.5 \\
(3.5 \pm 0.1)\end{array}$ \\
\hline
\end{tabular}

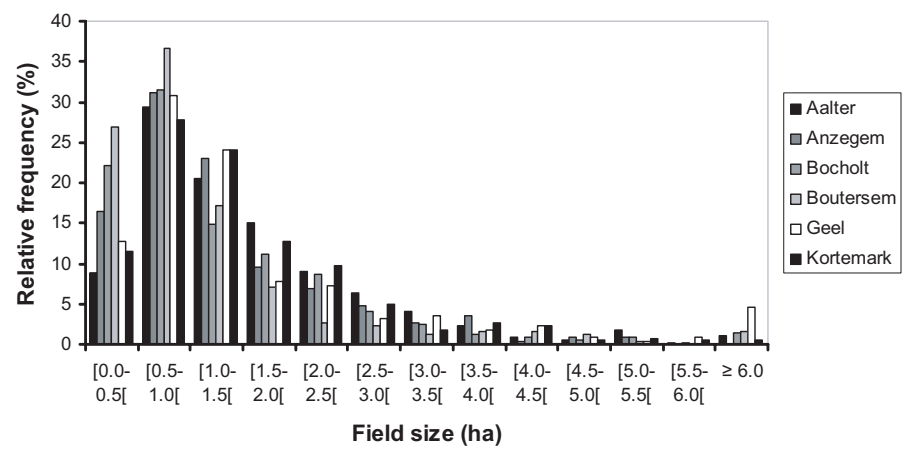

Figure 4. Size distribution of fields cropped with maize in six selected squares in Flanders.

the studied squares, maize fields having a size ranging between 0.5 and 0.9 ha were the most abundant (31\%).

Numbers of farmers growing maize ranged from 73 in Boutersem to 157 in Aalter. In Anzegem, each farmer had on average 2.4 maize fields, compared with 4.4 in Bocholt.

Although the data used only refer to the year 2004, they are very representative for maize growing in the selected squares, because they are quite similar to the means of the three most recent years. Most of the data that will be discussed further on correspond to Anzegem and Bocholt: the maize shares in the squares of the other clusters lay in-between these two extremes.

\subsection{Intra-regional variability}

Maize shares varied between the studied squares, with the highest share being observed in Bocholt (29\%), followed by Aalter (26\%), Geel (21\%), Kortemark (21\%), Boutersem (11\%) and Anzegem (11\%). This intra-regional variability largely affected the feasibility of implementing isolation perimeters. Depending on the scenarios and the imposed isolation perimeters, the proportions of non-GM maize fields and their corresponding farmers falling within the isolation perimeters were approximately two to four times higher in Bocholt than in Anzegem, except for S1 where the largest differences were observed between Bocholt and Boutersem. Not surprisingly, intra-regional differences decreased with increasing GM maize shares and isolation perimeter widths. Detailed data are presented in Tables III and IV; some striking examples are illustrated in Figures 5, 6 and 7.

When $10 \%$ of the farmers with the largest maize areas grow GM maize on their largest maize field (S1), an isolation perimeter of $260 \mathrm{~m}$ provoked approximately $1 / 3$ of all the GM maize fields to occur within the isolation perimeter in Bocholt. In Anzegem, this perimeter exceeded 300 m (Fig. 5a; Tab. III). In Bocholt, an isolation perimeter of $110 \mathrm{~m}$ involved $1 / 3$ of all the non-GM maize farmers, whilst in Anzegem the corresponding isolation perimeter was still wider than $300 \mathrm{~m}$ (Fig. 5b; Tab. III).

Given that $10 \%$ of the farmers with the largest maize areas grow GM maize on all their maize fields (S2), 1/3 of all non-GM maize fields fell within isolation perimeters smaller than $10 \mathrm{~m}$ in Bocholt, compared with an isolation perimeter of $165 \mathrm{~m}$ in Anzegem. Imposing an isolation perimeter smaller than $10 \mathrm{~m}$ in Bocholt and an isolation perimeter of $120 \mathrm{~m}$ 
(a)

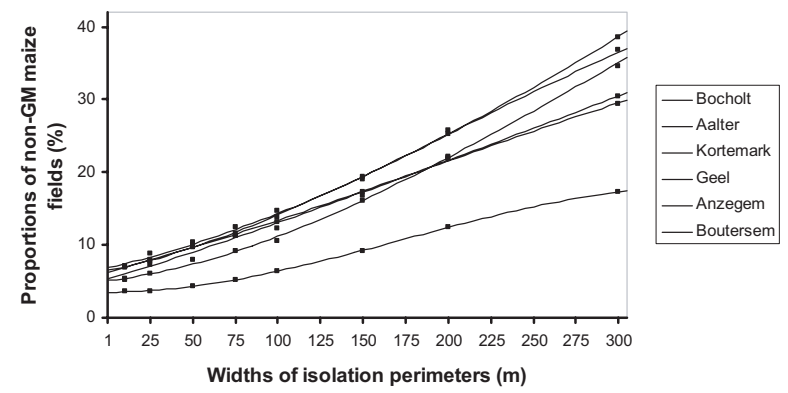

(b)

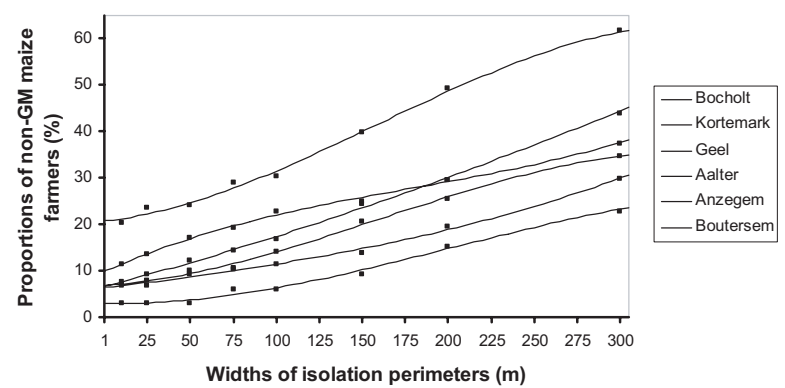

Figure 5. Scenario S1: Proportions of non-GM maize fields (a) and farmers having at least one non-GM maize field (b) falling within an isolation perimeter in relation to the isolation perimeter widths (situation in six selected squares in Flanders; regression formulas are given in Tab. IV).

in Anzegem affected $1 / 3$ of all the non-GM maize farmers (Tab. III).

In the case where $10 \%$ of the maize fields are planted randomly with GM maize (S3), an isolation perimeter of $55 \mathrm{~m}$ provoked approximately $1 / 3$ of all non-GM maize fields to fall within the isolation perimeter in Bocholt. In Anzegem, this isolation perimeter was $235 \mathrm{~m}$ (Fig. 6a; Tab. III). With the implementation of an isolation perimeter smaller than $10 \mathrm{~m}$ in Bocholt and an isolation perimeter of $200 \mathrm{~m}$ in Anzegem, 1/3 of all the non-GM maize farmers had at least one non-GM maize field occurring within the isolation perimeter (Fig. 6b; Tab. III).

If GM maize is clustered as foreseen in S4, none of the tested isolation perimeters provoked $1 / 3$ of all the non-GM maize fields or farmers to be affected by the isolation perimeters. Although the clustering of GM maize fields largely reduced the proportions of non-GM maize fields and their corresponding farmers occurring within perimeters, intra-regional differences were maintained (Tab. III).

When $10 \%$ of the farmers, who are selected randomly, grow GM maize on all their maize fields (on-farm clusters; S5), 1/3 of all the non-GM maize fields occurred within an isolation perimeter of $105 \mathrm{~m}$ in Bocholt. The same effect was reached in Anzegem with a perimeter wider than $300 \mathrm{~m}$ (Fig. 7a; Tab. III). In Bocholt, the implementation of an isolation perimeter smaller than $10 \mathrm{~m}$ already involved $1 / 3$ of all the non-GM maize farmers, compared with an isolation perimeter of $225 \mathrm{~m}$ in Anzegem (Fig. 7b; Tab. III). (a)

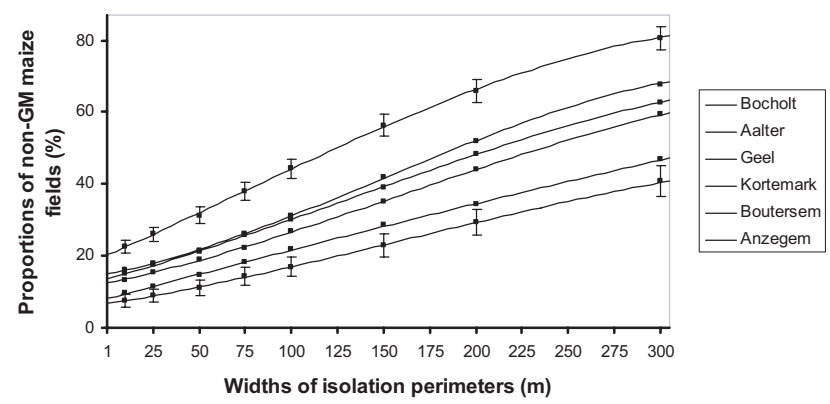

(b)

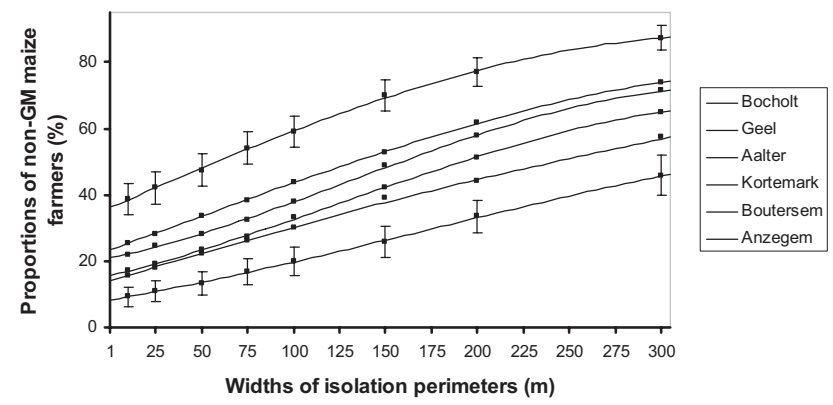

Figure 6. Scenario S3: Proportions of non-GM maize fields (a) and farmers that have at least one non-GM maize field (b) occurring within an isolation perimeter in relation to the isolation perimeter widths (situation in six selected squares in Flanders; to keep the figure clear, standard deviations are only given for Anzegem and Bocholt; regression formulas are provided in Tab. IV).
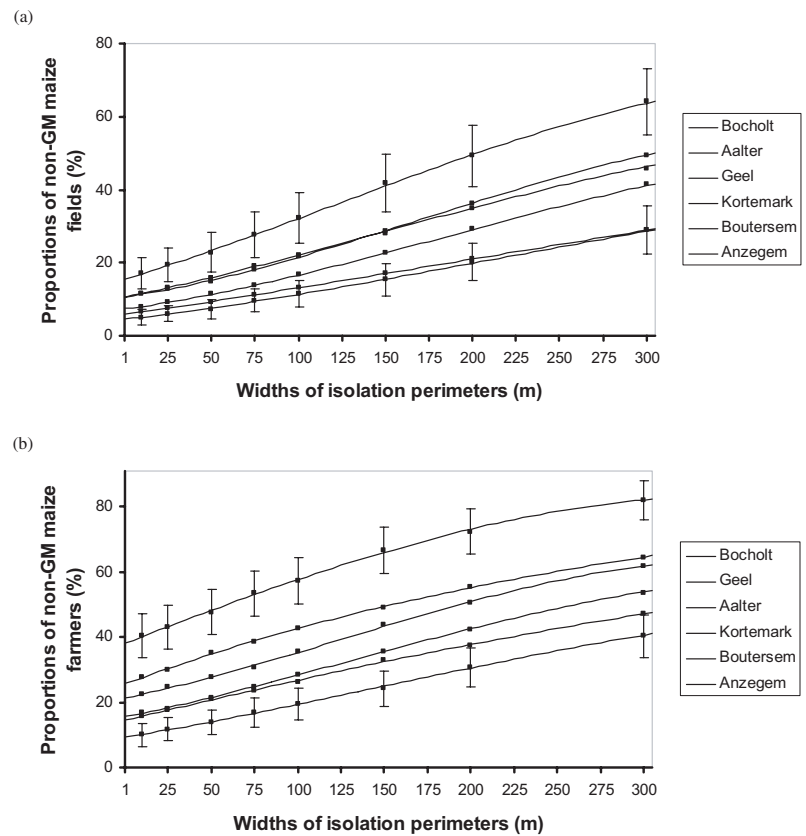

Figure 7. Scenario S5: Proportions of non-GM maize fields (a) and farmers having at least one non-GM maize field (b) occurring within an isolation perimeter in relation to the isolation perimeter widths (situation in six selected squares in Flanders; to keep the figure clear, standard deviations are only shown for Anzegem and Bocholt; regression formulas are provided in Tab. IV). 


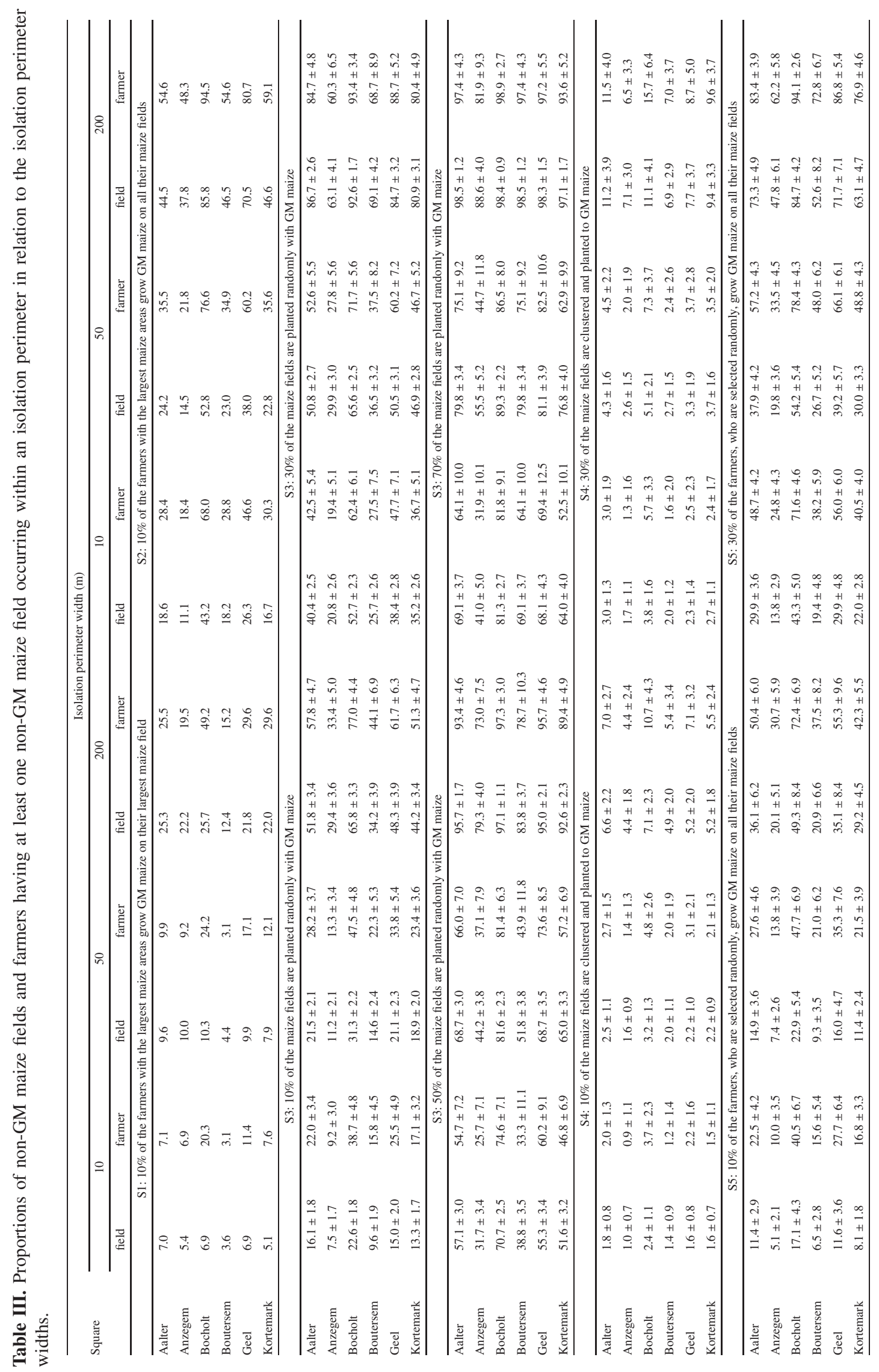


Besides the intra-regional variability in maize share, the feasibility of implementing isolation perimeters was also affected by the number, size and spatial distribution of GM maize fields (Devos et al., 2007). For example, the comparison of S1 and S5 indicated that for a given area or share of GM maize, growing this maize in a high number of small fields resulted in more spatial co-existence problems than growing the same area in a small number of large fields. Moreover, clustering GM maize fields into a large cluster (S4) reduced the proportions of non-GM maize fields and farmers having at least one non-GM maize field occurring within isolation perimeters five to ten times, compared with a similar situation in which GM maize fields are randomly distributed (S3).

Although further research is needed to quantify better the respective contributions of number, size, and of spatial distribution of maize fields on the feasibility of implementing isolation perimeters, some facts were clear. Due to its high maize share and the high number of small maize fields, Bocholt represented the worst-case situation with the most spatial co-existence problems. In contrast, Anzegem and Boutersem represented the most optimal situation for the implementation of isolation perimeters: maize shares and the number and size of maize fields were the lowest from the six studied squares. Characterised by medium to high maize shares, by an intermediate number of maize fields and by large maize fields, the squares of Aalter, Kortemark and Geel represented intermediate situations compared with the extremes.

\subsection{Feasibility of spatial co-existence measures}

As has been demonstrated in some European regions such as Lower Austria, Styria and Burgenland in Austria (Dolezel et al., 2005) and Poitou-Charentes in France (Messéan et al., 2006), and in the eastern canton of Zurich in Switzerland (Sanvido et al., in press), our results confirm the difficulty of implementing wide isolation perimeters in the areas tested in Flanders (see also Devos et al., 2007). Nationally imposing wide and uniform isolation perimeters by law creates different problems.

First, current and ongoing research with grain maize demonstrates that in many cases isolation perimeters over $50 \mathrm{~m}$ are not necessary to keep the adventitious GMO content in the harvests of neighbouring fields due to crossfertilisation below 0.9\% (Devos et al., 2005; Messéan et al., 2006; Messeguer et al., 2006; Pla et al., 2006). This is even truer for fodder maize, since the transgene is diluted over both grains and vegetative plant parts. Less than half of the total plant dry matter originates from grains that can carry the transgene in fodder maize (Holst-Jensen et al., 2006; Weber et al., 2007; Sanvido et al., in press). Moreover, due to the huge pollen cloud hanging over large recipient fields that acts as a physical barrier and competitor for incoming pollen, larger fields are less prone to cross-fertilisation and may require less spatial isolation (Devos et al., 2005; Messéan et al., 2006).

Secondly, the implementation of wide isolation perimeters is unfeasible in areas where maize is grown on a large part of the agricultural area. Maize fields are so close to each other that each GM maize field interferes with many non-GM maize fields and their corresponding farmers. Put in another way: a minimum of GM maize fields (and farmers) touches a majority of non-GM maize fields (and farmers), whereas this would not be the case in areas with a low share of maize fields. The freedom of choice of farmers would be jeopardised according to the place where one lives, which is an important factor of inequality. On the one hand, it is to be expected that the potential benefits of GM maize are more significant in areas intensively cropped with maize, but on the other hand, wide isolation perimeters would involve so many neighbouring farmers that administrative co-existence burdens and the fear of ruining personal relationships might take away any incentive to grow GM maize.

In such situations, clustering GM maize (and non-GM maize) offers a better solution, but is hard to implement in a sustainable way in Flanders. If farmers talk to each other, it might be possible to group maize on each other's fields in order to produce the expected quantities. This clustering may lead to, or strengthen the monoculture of maize on specific fields, which collides with the principle of sustainable agriculture. To avoid this evolution, farmers will have to talk very intensively with each other in order to synchronise their crop rotations. Otherwise, we will end up with a completely unsustainable situation both in the ecological and the social meaning.

Short isolation perimeters make things much easier. If they are supplemented with a shift in sowing dates and/or the installation of a pollen barrier around the GM maize field, or when the outer rows of the non-GM maize field are considered as potentially contaminated, co-existence might in principle be feasible even in areas with a high maize share. However, a shift in sowing dates is not effective in a large part of the EU. It is only effective in Mediterranean regions where the window of suitable weather conditions is large enough to postpone sowing, and where this postponement does not induce yield penalties (Della Porta et al., 2006; Messeguer et al., 2006; Weber et al., 2007).

Pollen barriers around GM maize fields may be not very effective either, in the case where maize fields are small such as in Flanders (Della Porta et al., 2006; Gustafson et al., 2006). Because a maize barrier around the donor only traps pollen that flies low and that is not likely to disperse far, its effect is thought to remain very local and limited (Gustafson et al., 2006; Kuparinen et al., 2007). Moreover, this measure might create new practical problems: in the case of herbicideresistant maize, two different weed management regimes will have to be applied on a single field, as the pollen barrier consists of a non-GM herbicide-susceptible counterpart. Many research results indicate that the outer plant rows in a recipient maize field function as a zone that safeguards the centre of the field (Gustafson et al., 2006; Messeguer et al., 2006; Weber et al., 2007; Weekes et al., 2007). According to Della Porta et al. (2006), two outer plant rows of maize tend to reduce cross-fertilisation levels as effectively as twelve maize buffer rows around the pollen donor. If needed, borders closest to the pollen donor could be harvested separately, and be discarded or be classified as 'GM maize'. Feed manufacturers 


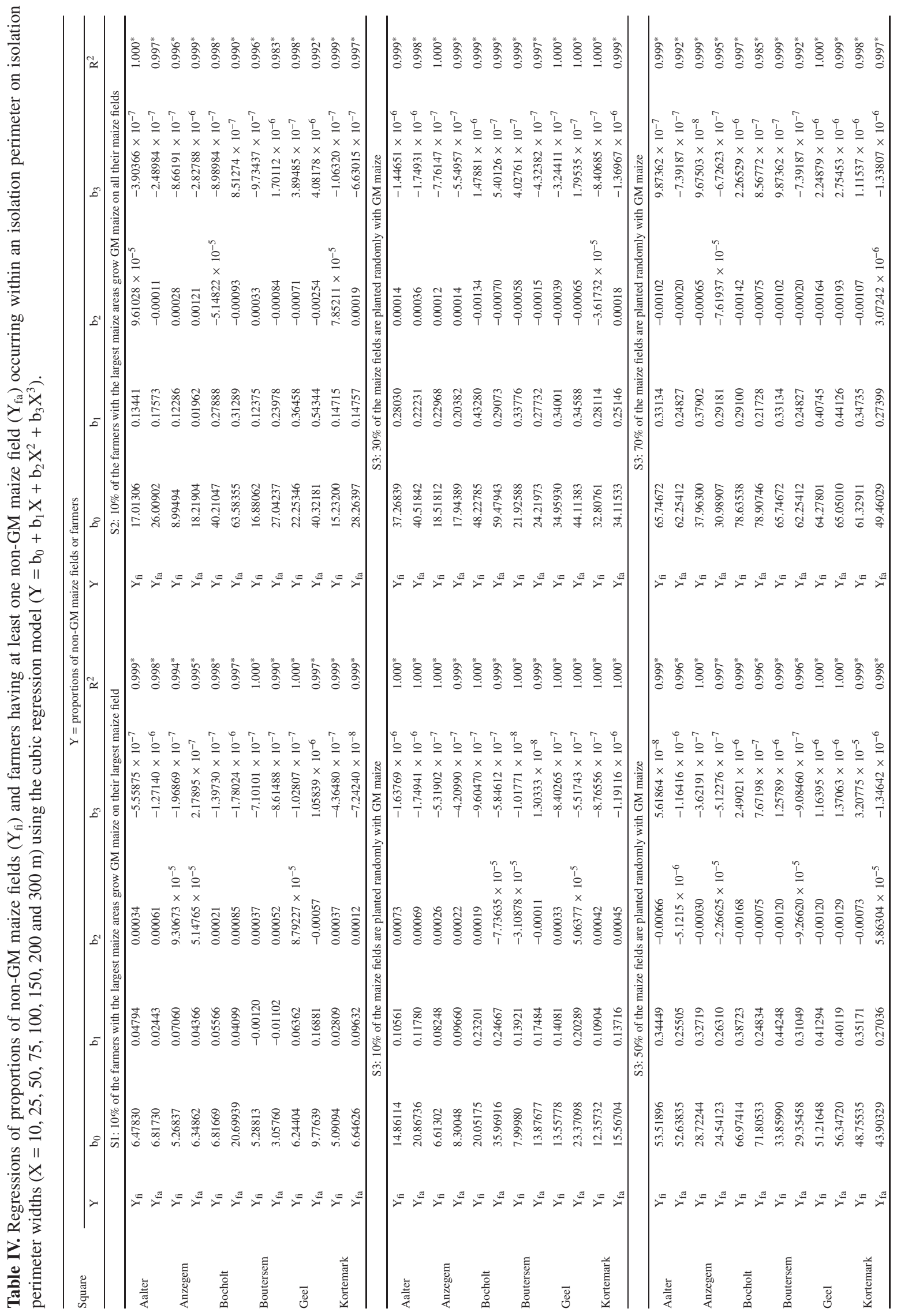




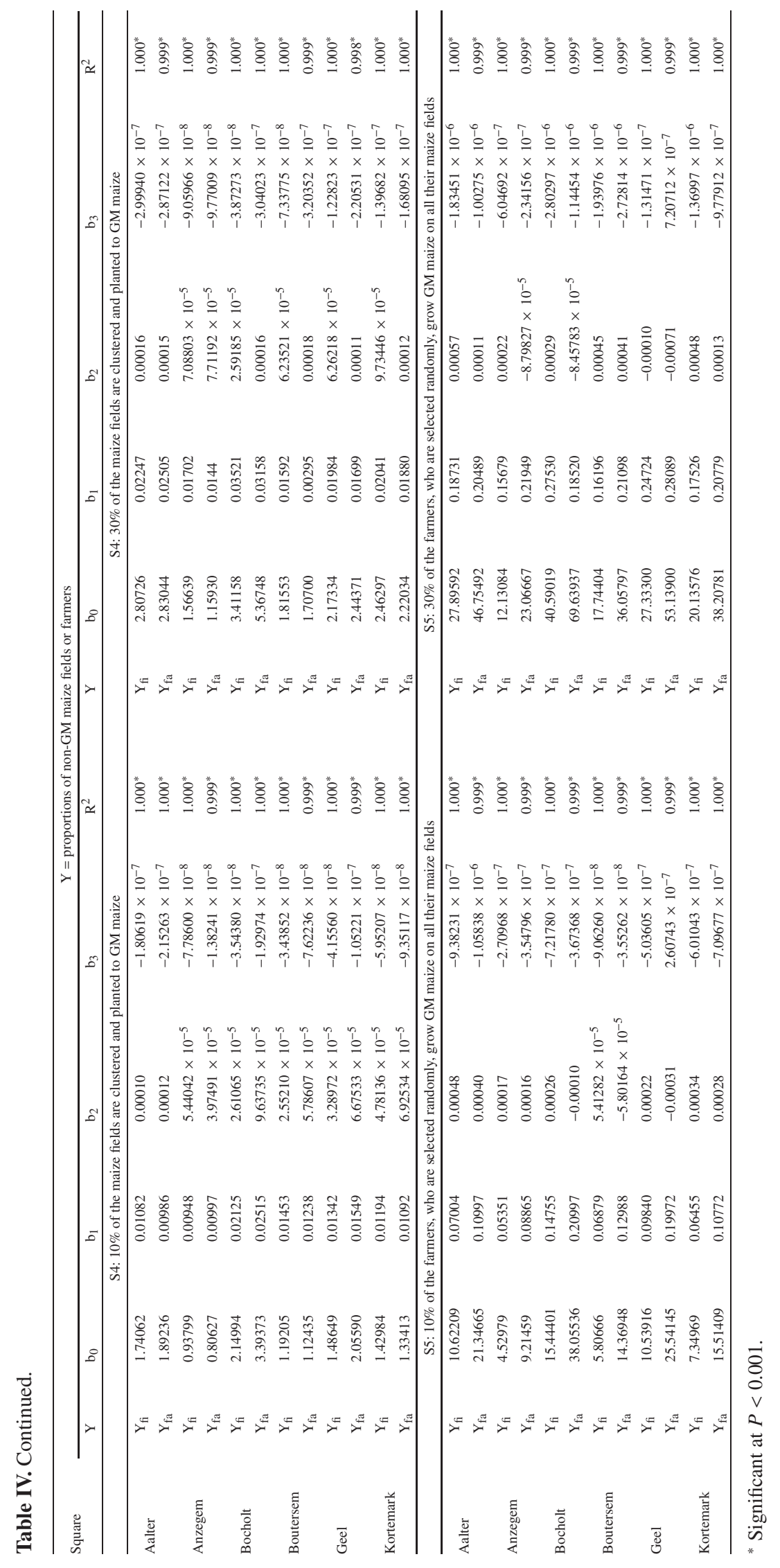


that import transgenic soybean to increase the protein content in feed could buy the maize that is classified as transgenic (Weber et al., 2006). However, it remains difficult to predict whether this approach will be workable in Flanders. Not only are the maize fields small, but most of the maize grown is used on-farm for silage production for cattle feed. Moreover, separately harvesting the borders and the centre of maize fields may generate new problems such as extra costs due to the cleaning of shared machinery. As such, a buffer zone in a cluster of fields can strengthen the benefits of both the clustering and the buffering system.

The advent of stacked GM maize events may further complicate the management of spatial co-existence. With the current trend to combine two or more transgenes into stacked GM maize events through traditional breeding, future GM maize hybrids will no longer contain a single transgene (De Schrijver et al., 2007). Because a stacked GM maize event contains more than one transgene, a similar cross-fertilisation rate may in the worst cases double or even triple the GMO content expressed in percentages of haploid genomes in recipient plants, compared with a single GM maize event (Holst-Jensen et al., 2006). As a consequence, it might be necessary to widen the isolation perimeter to comply with the $0.9 \%$ tolerance threshold, strengthening all the problems cited here above.

Because other sources than cross-fertilisation such as seed impurities, mixing in machinery and/or post-harvest procedures could lead to the adventitious presence of GM material in non-GM products in the agricultural context, the GM input from cross-fertilisations may have to remain substantially below $0.9 \%$ (e.g. $0.5 \%$ ). Hence, in some cases, tighter tolerance thresholds might have to be proposed to guarantee a GM content of $0.9 \%$ in the final product, which will have repercussions on the isolation perimeter needed (Devos et al., 2005; Messéan et al., 2006; Sanvido et al., in press).

\section{CONCLUSION}

According to the principle of subsidiarity, co-existence between cropping systems should be regulated as closely as possible to the farm in order to take the diversity of the agricultural landscape into account. Even in a small region like Flanders, the feasibility of implementing isolation perimeters will be largely affected by intra-regional differences in the maize share and in the size, the number and the distribution of maize fields. Hence, the freedom of choice of farmers to grow GM maize or not would be jeopardised according to the place where one lives, which is an important factor of inequality. To reflect intra- and inter-regional differences, legal co-existence frames should not simply rely on single and rigid co-existence measures, but build in a certain degree of flexibility by proposing plural co-existence measures that are adaptable to different agricultural and regional situations. Short isolation perimeters supplemented with a shift in sowing dates and/or with the installation of a pollen barrier offer similar guarantees to comply with the $0.9 \%$ threshold to wide isolation perimeters. Some national and/or regional authorities have already attempted to introduce some flexibility for managing cross-fertilisation be- tween neighbouring fields: in the Czech Republic, the isolation perimeter of $70 \mathrm{~m}$ towards conventional maize fields can be shortened provided that every two metres of isolation perimeter is replaced by a buffer row of non-GM maize around the GM maize fields in Sweden, isolation perimeters can range between 15 and $50 \mathrm{~m}$ depending on the type of maize and on the number of transgenes contained in the GM maize hybrids (EC, 2006). Although such a case-by-case-based approach will demand much administrative effort, it may be one step forward in reaching proportionate, fair and consistent co-existence at the regional and landscape level.

\section{REFERENCES}

Aylor D.E., Schultes N.P., Shields E.J. (2003) An aerobiological framework for assessing cross-pollination in maize, Agr. For. Meteorol. 119, 111-129.

Bannert M., Stamp P. (2007) Cross-pollination of maize at long distance, Eur. J. Agron. 27, 44-51.

De Schrijver A., Devos Y., Van den Bulcke M., Cadot P., De Loose M., Reheul D., Sneyers M. (2007) Risk assessment of GM stacked events obtained from crosses between GM events, Trends Food Sci. Tech. 18, 101-109.

Della Porta G., Ederle D., Bucchini L., Prandi M., Pozzi C., Verderio A. (2006) Gene flow between neighboring maize fields in the Po Valley: a fact-finding investigation regarding coexistence between conventional and non-conventional maize farming in the region of Lombardy, Italy. Report, Centro Documentazione Agrobiotechnologie, Milan, Italy.

Demeke T., Perry D.J., Scowcroft W.R. (2006) Adventitions presence of GMOs: scientific overview for Canadian grains, Can. J. Plant Sci. $86,1-23$.

Devaux C., Lavigne C., Austerlitz F., Klein E.K. (2007) Modelling and estimating pollen movement in oilseed rape (Brassica napus) at the landscape scale using genetic markers, Mol. Ecol. 16, 487-499.

Devos Y., Reheul D., De Schrijver A., Cors F., Moens W. (2004) Management of herbicide-tolerant oilseed rape in Europe: a case study on minimizing vertical gene flow, Environ. Biosafety Res. 3, 135-148.

Devos Y., Reheul D., De Schrijver A. (2005) The co-existence between transgenic and non-transgenic maize in the European Union: a focus on pollen flow and cross-fertilization, Environ. Biosafety Res. 4, 71-87.

Devos Y., Reheul D., De Waele D., Van Speybroeck L. (2006) The interplay between societal concerns and the regulatory frame on GM crops in the European Union, Environ. Biosafety Res. 5, 127-149.

Devos Y., Reheul D., Thas O., De Clercq E.M., Cougnon M., Cordemans K. (2007) Implementing isolation perimeters around genetically modified maize fields, Agron. Sustain. Dev. 27, 155-165.

Dolezel M., Pascher K., Grabherr G. (2005) Regionality as a key parameter for co-existence of genetically modified maize with conventional and organic maize, in: Messéan A. (Ed.), Proceedings of the 2nd International Conference on Co-existence between GM and non-GM based agricultural supply chains, Agropolis Productions, Montpellier, pp. 203-206.

EC (2003a) Commission Recommendation of 23 July 2003 on guidelines for the development of national strategies and best practices to ensure the coexistence of genetically modified crops with conventional and organic farming, Official J. European Comm. L189, $36-47$.

EC (2003b) Regulation (EC) 1829/2003 of the European Parliament and of the Council of 22 September 2003 on genetically modified food and feed, Official J. European Comm. L268, 1-23. 
EC (2006) Report on the implementation of national measures on the co-existence of genetically modified crops with conventional and organic farming.

Friesen L.F., Nelson A.G., Van Acker R.C. (2003) Evidence of contamination of pedigreed canola (Brassica napus) seedlots in western Canada with genetically modified herbicide resistance traits, Agron. J. 95, 1342-1347.

Gustafson D.I., Brants I.O., Horak M.J., Remund K.M., Rosenbaum E.W., Soteres J.K. (2006) Empirical modeling of genetically modified maize grain production practices to achieve European Union labeling thresholds, Crop Sci. 46, 2133-2140.

Holst-Jensen A., De Loose M., van den Eede G. (2006) Coherence between legal requirements and approaches for detection of genetically modified organisms (GMOs) and their derived products, J. Agr. Food Chem. 54, 2799-2809.

Jarosz N., Loubet B., Durand B., Foueillassar X., Huber L. (2005) Variations in maize pollen emission and deposition in relation to microclimate, Environ. Sci. Tech. 39, 4377-4384.

Kuparinen A., Schurr F., Tackenberg O., O'Hara RB. (2007) Airmediated pollen flow from genetically modified to conventional crops, Ecol. Appl. 17, 431-440.

Lutman P.J.W., Berry K., Payne R.W., Simpson E., Sweet J.B., Champion G.T., May M.J., Wightman P., Walker K., Lainsbury M. (2005) Persistence of seeds from crops of conventional and herbicide tolerant oilseed rape (Brassica napus), Proc. R. Soc. Lond. B 272, 1909-1915.

Marvier M., Van Acker R.C. (2005) Can crop transgenes be kept on a leash? Front. Ecol. Environ. 3, 99-106.

Messéan A., Angevin F., Gómez-Barbero M., Menrad K., RodríguezCerezo E. (2006) New case studies on the coexistence of GM and non-GM crops in European agriculture. Report, Joint Research Centre and Institute for Prospective Technological Studies, Seville, Spain.

Messéan A., Sausse C., Gasquez J., Darmency H. (2007) Occurrence of genetically modified oilseed rape seeds in the harvests of subsequent conventional oilseed rape over time, Eur. J. Agron. 27, 115122.
Messeguer J., Peñas G., Ballester J., Bas M., Serra J., Salvia J., Palaudelmàs M., Melé E. (2006) Pollen-mediated gene flow in maize in real situations of coexistence, Plant Biotechnol. J. 4, 633645.

Pla M., La Paz J.-L., Peñas G., García N., Palaudelmàs M., Esteve T., Messeguer J., Melé E. (2006) Assessment of real-time PCR based methods for quantification of pollen-mediated gene flow from GM to conventional maize in a field study, Transgenic Res. 15, 219-228.

Sanvido O., Widmer F., Winzeler M., Streit B., Szerencsits E., Bigler F. (in press) Definition and feasibility of isolation distance for transgenic maize, Transgenic Res., doi:10.1007/s11248-007-9103-1.

Schiemann J. (2003) Co-existence of genetically modified crops with conventional and organic farming, Environ. Biosafety Res. 2, 213217.

Van De Wiel C.C.M., Lotz L.A.P. (2006) Outcrossing and coexistence of genetically modified with (genetically) unmodified crops: a case study of the situation in the Netherlands, Neth. J. Agr. Sci. 54, 1735.

Weber W.E., Bringezu T., Pohl M., Gerstenkorn D. (2006) Bt maize farmers and grain trade implement coexistence, Mais 2, 2-4.

Weber W.E., Bringezu T., Broer I., Holz F., Eder J. (2007) Coexistence between GM and non-GM maize crops - tested in 2004 at the field scale level (Erprobungsanbau 2004), J. Agron. Crop Sci. 193, 7992.

Weekes R., Allnutt T., Boffey C., Morgan S., Bilton M., Daniels R., Henry C. (2007) A study of crop-to-crop gene flow using farm scale sites of fodder maize (Zea mays L.) in the UK, Transgenic Res. 16, 203211.

Yoshimura Y., Beckie H.J., Matsuo K. (2006) Transgenic oilseed rape along transportation routes and port of Vancouver in western Canada, Environ. Biosafety Res. 5, 67-75. 